\title{
Nulla Poena Sine Lege in Continental Criminal Law: Historical and Theoretical Analysis
}

\section{Evgeny Tikhonravov}

\begin{abstract}
Multiple viewpoints have been expressed regarding the principle nulla poena sine lege (there exists no punishment without a pre-existing penal law). Some scholars advocate the inviolability of this maxim because it safeguards personal freedom - an opportunity to do everything not prohibited by law. However, its critics assert that rigid adherence to the principle nulla poena sine lege may do more harm than good. They argue that the maxim, while prohibiting judges from punishing noncriminal acts, makes it impossible for courts to deter them in a timely manner, which, in certain cases, may have a detrimental effect on society. To determine the correct approach to nulla poena sine lege, the paper considers its history in continental criminal law and then analyses the principle theoretically. The examination reveals that two contradictory interests - the need to safeguard personal freedom and the need to combat lawful, yet socially harmful, acts through judicial punishment - cannot be completely ignored in practice. Therefore, the findings suggest a balancing between these interests and propose a way to achieve this compromise.
\end{abstract}

Keywords: nulla poena sine lege; punishment by analogy; personal freedom; legal fiction

This article proceeds as follows. Section 1 explores legislative acts and judicial practice of various European countries concerning the punishment for acts which were not explicitly criminalised at the time of commission. Section 2 provides theoretical analysis of different approaches which are adopted in these acts and practice. Finally, the paper ends with a conclusion in which the correct approach is suggested.

In the early modern period, a number of European statutes authorised courts to punish acts which were not expressly crimilised by the sovereign. Among these laws were, for instance, Halsgerichtsordnungen für Tirol (1499) ${ }^{1}$ and Österreich unter der Enns Landgerichtsordnung $(1514){ }^{2}$

Often the judicial practice concerning the application of these laws was arbitrary. ${ }^{3}$ In order to restrain the abuse of powers by the judiciary, Bambergensis (1507), Brandenburgensis (1516), and the Constitutio Criminalis Carolina (1532) imposed a duty on judges to submit a case not specified by the criminal law to a legislative organ and to enquire how it should be solved. ${ }^{4}$ This procedure, however, was regularly ignored and achieved no considerable success. ${ }^{5}$

In the 18th century, one can still find enactments authorising courts to penalise acts which were not explicitly criminalised at the time of commission. These were, for example, the 1721 Prussian Code, the 1751 Bavarian Code, and the 1769 Constitutio Criminalis Theresiana. ${ }^{6}$

With the advent of the Age of Enlightenment, some prominent political scholars and philosophers took a firm stand against the wide discretion of the judiciary. With this regard, the

\footnotetext{
${ }^{1}$ B. Ackermann, 'Das Analogieverbot im geltenden und zukünftigen Strafrecht' (Breslau-Neukirch 1934) 6

${ }^{2}$ Ф. П. Дубровин, 'О размерах допустимости аналогии при применении уголовного закона' [1899] 5 Журнал министерства юстиции 130

3 Ibid. 129, 133; E. Rejewski, 'Die Stellung des Strafrichters zur 'Schuldfrage' unter dem Gesichtswinkel der Abgrenzung der ausdehnenden Auslegung zur Analogie' (Inaugural-Dissertation zur Erlangung der Doktorwürde. Breslau-Neukirch 1937) 19-20

${ }_{5}^{4}$ Дубровин, supra note 3, at 130

5 Ibid. 132; Ackermann, supra note 2, at 7; Rejewski, supra note 4, at 20, 35

6 J. Hall,'Nulla Poena Sine Lege' [1937] 47 The Yale Law Journal 168
} 
names of C.-L. de Montesquieu and C. Beccaria are often cited. ${ }^{7}$ They proposed to dramatically limit the competence of courts and to reduce their powers to the mere application of the law. ${ }^{8}$

Soon these ideas found their way into legislative acts. In 1787, the Holy Roman Emperor, Joseph II, influenced by the enlightenment beliefs, ${ }^{9}$ enacted the Penal Code of Austria. Its part I $\S 1$ provides as follows: "Only those illegal acts are to be considered and treated as crimes which have been declared to be as such by the present law." 10

It is generally accepted ${ }^{11}$ that this article was the first to adopt the principle which was later expressed by P. J. A. v. Feuerbach in a Latin formula 'nulla poena sine lege': no penalty without a law. ${ }^{12}$ Later similar provisions were incorporated in the 1789 Declaration of Human and Civil Rights (art. 7 and 8), ${ }^{13}$ the 1794 Prussian Law (title 20, part II, § 2), ${ }^{14}$ the 1810 French Criminal Code (art. 10), ${ }^{15}$ the 1813 Bavarian Penal Code (art. 1), ${ }^{16}$ the 1851 Prussian Penal Code ${ }^{17}$ and the 1871 German Penal Code (§ 2, par. 1). ${ }^{18}$

Although the punishment for non-criminal acts was forbidden, it did not, as E. Ehrlich concluded, ${ }^{19}$ cease to exist in legal practice. To quote I. Anosov, "If we turn to practice, we will see, as one would expect, that this maxim [nulla poena sine lege], this axiom of the modern criminal law, was violated when it was (or appeared to be) favourable or necessary. The idea that not all crimes are listed in criminal codes governs the practice." 20

The words of E. Ehrlich and I. Anosov can be confirmed by a classic illustration: the unauthorised appropriation of electricity. At first, it was not prohibited by criminal codes as the legislators simply did not foresee the possibility of this act. Nevertheless, judges in the Netherlands ${ }^{21}$ and France ${ }^{22}$ meted out punishment for it.

The same approach was adopted by courts in Bavaria: on 15 January 1895, the Oberlandsgericht (Higher Regional Court) Munich reached a guilty verdict on this matter. ${ }^{23}$ By contrast, on 1 May 1899, the Supreme Court of the German Reich held that "the unauthorized tapping of an electric power line did not constitute theft." 24 This way of dealing with the unauthorised appropriation of electricity was also employed in Switzerland. ${ }^{25}$ However, in some

\footnotetext{
7 Дубровин, supra note 3, at 135-136; S. Glaser,'Nullum Crimen Sine Lege' [1942] 24 Journal of Comparative Legislation and International Law 30; A. Mokhtar,'Nullum Crimen, Nulla Poena Sine Lege: Aspects and Prospects' [2005] 26 Statute Law Review 45-46

${ }^{8}$ Дубровин, supra note 3, at 135-136; Glaser, supra note 8, at 30; Mokhtar, supra note 8, at 45-46

${ }^{9}$ V. Krey, 'Studien zum Gesetzesvorbehalt im Strafrecht: Eine Einführung in die Problematik des Analogieverbots' (Berlin: Duncker \& Humblot 1977) 209

${ }^{10}$ Ibid. 208

${ }^{11}$ Hall, supra note 7, at 168; Glaser, supra note 8 , at 30

${ }^{12}$ P. J. A. v. Feuerbach, 'Lehrbuch des gemeinen in Deutschland gültigen peinlichen Rechts' (Giessen: Georg Friedrich Heyer's Verlag 1847) 41

${ }^{13}$ Available at: http://www.conseil-constitutionnel.fr/conseil-constitutionnel/root/bank_mm/anglais/cst2.pdf

${ }^{14}$ Krey, supra note 10 , at 208

${ }^{15}$ Hall, supra note 7, at 169

${ }^{16}$ Ackermann, supra note 2 , at 9

${ }^{17}$ Hall, supra note 7, at 169

18 L. Preuss, 'Punishment by Analogy in National Socialist Penal Law' [1936] 26 Journal of Criminal Law and Criminology 847

${ }^{19}$ E. Ehrlich, 'Die juristische Logik' (Tübingen 1925) 226

${ }^{20}$ И. И. Аносов, ‘Заметки к вопросу о применении аналогии в уголовном праве’ [1926] 5 Бюллетень Среднеазиатского государственного университета 4-5

${ }^{21}$ C. W. Maris, 'Milking the Meter - On analogy, Universalizability and World Views' In 'Legal knowledge and analogy: fragments of legal epistemology, hermeneutics, and linguistics' (Dordrecht: Kluwer Academic Publishers, 1991) 71

${ }^{22}$ Ibid. 77

${ }^{23}$ И. В. Гессен, ‘Творческая роль суда (примеры из практики)’ [1897] 6 Журнал Министерства Юстиции 218

${ }^{24}$ Preuss, supra note 19 , at 851

${ }^{25}$ Maris, supra note 22, at 77
} 
other cases ${ }^{26}$ German courts did not hold to the legally accepted maxim nulla poena sine lege which Germany, along with three other mentioned countries, incorporated in its criminal law. ${ }^{27}$

The similar practice can be observed in the Russian Empire. Article 771 of the 1864 Statute of the Criminal Procedure declared that "the court shall acquit the accused if an act he was charged with is not prohibited by laws under the threat of punishment." ${ }^{28}$ Despite this provision, in 1868, the Governing Senate, the Supreme Court of the Russian Empire, ruled that "an act, though not prohibited by any article of the law, can be punished if acceptance of this act may lead to serious abuse. ${ }^{, 29}$ In other words, in some circumstances judges did not adhere to the legal principle nulla poena sine lege.

In the 20th century, it was, however, abolished in several countries. ${ }^{30}$ For instance, in the Russian Soviet Federative Socialist Republic and later in the USSR courts were authorised to penalise acts which were not specified by the law. In this regard, article 6 of the 1922 Criminal Code of the RSFSR defined crime as "any socially dangerous conduct or omission posing a threat to underlying principles of the soviet state and legal order established by the power of industrial workers and peasants for the transitional period to the communist order." ${ }^{31}$ The definition corresponded with article 10 of the same code which declared that "when there are no direct references to particular crimes in the criminal code, penalties or means of social defence shall be applied according to the provisions of the criminal code which provide for crimes which are the most similar in their importance and their kind, in compliance with the rules of the general part of the code." 32

This rule in a slightly different wording was transferred into article 16 of the 1926 Criminal Code of the RSFSR. ${ }^{33}$ It is worth noting that its application was widespread. For example, in 1939, a group of scholars came to conclusion that in twenty months, the courts of Moscow region and the Moscow City Court have applied fifty-three provisions, which made up one third of the articles of the special part of the code, in accordance with its article $16 .^{34}$ This practice was condemned as "dangerous and politically harmful." 35 Another team of researchers asserted that the application of article 16 was "occasionally coupled with the outrageous perversion of the socialist criminal law.",36

In 1958, the maxim nulla poena sine lege entered into article 7 of the 1958 Basic Principles of the Criminal Legislature of the USSR and Union Republics. ${ }^{37}$ However, as M. A. Kaufman maintains, judges continued to punish non-criminal conduct, but they ably camouflaged this practice. ${ }^{38}$

On 28 June 1935, the 1871 German Penal Code was amended to permit judges to mete out punishment for acts which were not specified in it. ${ }^{39}$ Nevertheless, in the Third Reich the use of this

\footnotetext{
${ }^{26}$ Rejewski, supra note 4, at 33-34

${ }^{27}$ Maris, supra note 22, at 77

28 Устав уголовного судопроизводства 1864 г. // Свод законов Российской Империи. Т. XVI. Ч. 1. СПб., 1912. 446

${ }^{29}$ Ф. П. Дубровин, 'О размерах допустимости аналогии при применении уголовного закона (окончание)’ [1899] 6 Журнал Министерства юстиции 29-30

${ }^{30}$ Glaser, supra note 8 , at 32-33

31 Постановление ВЦИК от 01.06.1922 «О введении в действие Уголовного Кодекса РСФСР» (вместе с Уголовным Кодексом РСФСР) // СУ РСФСР, 1922, № 15, ст. 153

32 Ibid.

33 Постановление ВЦИК от 22.11.1926 «О введении в действие Уголовного Кодекса РСФСР редакции 1926 года» (вместе с Уголовным Кодексом РСФСР) // СУ РСФСР, 1926, № 80, ст. 600

${ }^{34}$ П. В. 'Понятие аналогии в советском уголовном праве и практика ее применения' [1939] 3 Советская юстиция 12

${ }^{35}$ Ibid.

36 'К разработке проекта общей части Уголовного кодекса СССР' [1938] 20-21 Советская юстиция 18

${ }_{37}$ Основы уголовного законодательства Союза ССР и союзных республик 1958 г. // Ведомости ВС СССР, 1959 , № 1 , ст. 6

${ }^{38}$ М. А. Кауфман, ‘Пробелы в уголовном праве и способы их преодоления’ (автореф. дис. ... док. юрид. наук. M., 2009) 40

${ }^{39}$ Preuss, supra note 19 , at 847 ; Glaser, supra note 8 , at 33
} 
possibility was not excessive..$^{40}$ It may be speculated that this is probably so because "legislation could be enacted with lightning speed since the Fuehrer had unlimited legislative power." ${ }^{41}$ In addition, "from the beginning those who were considered of real danger to the regime were dealt with by methods other than the criminal law." ${ }^{2}$ The amendment was abolished on 31 January $1946 .{ }^{43}$

The brief historical analysis presents two legislative approaches: the maxim nulla poena sine lege can be either accepted or denied by the sovereign. The second option implies not only the legislative rejection of the principle, but also the sovereign's tacit consent to judicial violation of the principle when it is declared to be legally binding.

These two approaches are based on different theoretical concepts. Scholars advocating the maxim nulla poena sine lege stress the inviolability of civil freedom. The latter can be conceived of as "an opportunity to do everything which is not prohibited by the law." 44 Its paramount importance was expressed by V. Spasovich as follows: "Harm caused by a villainy committed with impunity as it was omitted by the law cannot be compared with terrible damage produced by the punishment without legitimate grounds and with the restriction of civil freedom which results from it." 45

On the other hand, researchers who defend the opposite approach argue that due to this maxim acts which are not criminal but at the same time detrimental to society and present the risk of disorder for the state cannot be punished and in this way prevented in a timely manner. ${ }^{46}$ It is therefore not surprising that F. Liszt described a criminal code which adopts this maxim as the "magna charta of the delinquent.",

According to P. Danckert, these two approaches were thoroughly discussed in the draft of the 1851 Prussian Penal Code. ${ }^{48}$ As a result, the principle nulla poena sine lege prevailed. ${ }^{49}$ At the present time, its primacy is recognised virtually all over the world: the maxim is embodied in article 11 of the Universal Declaration of Human Rights ${ }^{50}$ and article 15 of the International Covenant on Civil and Political Rights. ${ }^{51}$

Under these circumstances, judges are legally obliged to punish only those acts which were declared to be criminal at the time of commission. Nevertheless, rigid adherence to the maxim nulla poena sine lege appears to do more harm than good. This conclusion is based, in particular, on the considerations of J. Locke and R. Jhering.

In his work 'Two Treatises of Government,' J. Locke argued, "Where the legislative and executive power are in distinct hands ... there the good of the society requires, that several things should be left to the discretion of him that has the executive power: for the legislators not being able to foresee, and provide by laws, for all that may be useful to the community, the executor of the laws having the power in his hands, has by the common law of nature a right to make use of it for the good of the society, in many cases, where the municipal law has given no direction, till the legislative can conveniently be assembled to provide for it. Many things there are, which the law can by no means provide for; and those must necessarily be left to the discretion of him that has the executive power in his hands, to be ordered by him as the public good and advantage shall require:

\footnotetext{
${ }^{40}$ Hall, supra note 7, at 175-176; 'The Use of Analogy in Criminal Law' [1947] 47 Columbia Law Review 616; M. Boot, 'Genocide, Crimes Against Humanity, War Crimes: Nullum Crimen Sine Lege and the Subject Matter Jurisdiction of the International Criminal Court' (Intersentia 2002) 87

41 'The Use of Analogy in Criminal Law,' supra note 41, at 616 (footnote omitted)

${ }^{42}$ Ibid. (footnote omitted)

${ }^{43}$ Boot, supra note 41 , at 87

${ }^{44}$ В. Д. Спасович, 'Учебник уголовного права. Т. І' (СПб. 1863) 170

45 Ibid.

${ }^{46}$ Preuss, supra note 19, at 847-848; Rejewski, supra note 4, at 2-3; 'The Use of Analogy in Criminal Law,' supra note 40, at 628-629

${ }^{47}$ Glaser, supra note 8 , at 34

${ }^{48}$ P. Danckert, 'Die Grenze zwischen der extensiven Auslegung und der Analogie im Strafrecht' (Inaugural-Dissertation zur Erlangung der Doktorwürde. 1967) 41

${ }^{49}$ Ibid. 43

${ }^{50}$ G.A. Res. 217A(III), U.N. Doc. A/810 (1948)

${ }^{51}$ 1966, 999 U.N.T.S. 171
} 
nay, it is fit that the laws themselves should in some cases give way to the executive power, or rather to this fundamental law of nature and government, viz. That as much as may be all the members of the society are to be preserved: for since many accidents may happen, wherein a strict and rigid observation of the laws may do harm ... This power to act according to discretion, for the public good, without the prescription of the law, and sometimes even against it, is that which is called prerogative: for since in some governments the law-making power is not always in being, and is usually too numerous, and so too slow, for the dispatch requisite to execution; and because also it is impossible to foresee, and so by laws to provide for, all accidents and necessities that may concern the public, or to make such laws as will do no harm, if they are executed with an inflexible rigour, on all occasions, and upon all persons that may come in their way; therefore there is a latitude left to the executive power, to do many things of choice which the laws do not prescribe. This power, whilst employed for the benefit of the community, and suitably to the trust and ends of the government, is undoubted prerogative, and never is questioned." 52

Similar ideas were formulated by R. Jhering. As he maintained, "Law exists for the sake of society, not society for the sake of law. Hence, it follows that when in cases ... the relations are such that the government finds itself facing the alternatives of sacrificing either the law or society, it is not merely empowered, but in duty bound, to sacrifice law and save society. For higher than the law which it violates stands the consideration for the preservation of society, in the service of which all laws must stand." 53

The cited arguments lend support for the view that the legal principle nulla poena sine lege can be neglected. However, they differ in one respect. Whereas R. Jhering maintained that the law should be sacrificed only "for the preservation of society," that is when a non-criminal act poses a serious threat to it, J. Locke argued that the executive power is authorised to act against the law "for the public good." Consequently, according to the latter opinion, judges are empowered by prerogative to neglect the maxim nulla poena sine lege not only in cases when non-criminal conduct presents a grave danger to society, but also when the benefit of the community brought by nonobservance of the principle greatly outweighs the harm inflicted by its infringement.

Considering the aim of ensuring the good of the society, it is to conclude that J. Locke's stance is the correct one. Moreover, this view was often adopted by the judiciary. A case concerning the unauthorised appropriation of the electricity is a good example here. In addition, the Nuremberg Tribunals diluted the rigidity of the maxim nulla poena sine lege, even though it "was recognized at this time as a general principle of criminal law and a principle of justice." 54

However, the breach of legality caused by the violation of this legal maxim is always detrimental to society as its people may follow the example of judges. As R. Pound put it, "If the courts do not respect the law, who will?"55

It is necessary therefore to camouflage the breach of legality. One of the possible methods for achieving this goal is the employment of a so-called creative legal fiction. It is "an assumption which conceals or attempts to conceal the fact that under the guise of application of a legal rule a certain state body formulates and implements a ruling which cannot be derived from this legal rule." $" 56$

A creative legal fiction is used when a judge, for example, while punishing non-criminal conduct states that he applies an existing legal rule to reach a guilty verdict. This way camouflages the breach of legitimacy behind a veil of legal application and gives an impression, though a false one, that a court's decision is legally justified.

\footnotetext{
${ }^{52}$ J. Locke, 'Two Treatises of Government' (London 1821) 327-329

${ }^{53}$ R. Jhering, 'Law as a Means to an End' (Boston 1913) 317

${ }^{54}$ Mokhtar, supra note 8, at 53

${ }^{55}$ R. Pound, 'An Introduction to the Philosophy of Law' (Clark, New Jersey 2003) 123

56 E. Tikhonravov, 'The Process of Filling Gaps in the Law as a Specific Political Activity' In 'Integrating Social Sciences into Legal Research: International Conference of PhD Students and Young Researchers' (Vilnius: Vilnius University 2014, available

http://www.tf.vu.1t/dokumentai/Admin/PhD_konferencija_2014/Conference_Papers_2014.pdf) 304
} 
For instance, in 1921, this method was used by the Dutch Supreme Court in a case concerning the unauthorised appropriation of electricity. To punish this non-criminal act, the court resorted to article 310 of the penal code. This provision "dated from a time - 1881 - that no legislator had ever thought of the possibility of stealing something immaterial like energy" ${ }^{\prime 57}$ and referred therefore only to a tangible object. Nevertheless, the court held that electricity is similar to "tangible property" and applied article 310 of the penal code to arrive to a guilty verdict. ${ }^{58}$

The findings of this paper reinforce the view that non-criminal acts should be punished by courts when the benefit of the community brought by the violation of the legal principle nulla poena sine lege greatly outweighs the harm inflicted by its infringement. In this case, however, creative legal fictions should be employed to conceal the breach of legality.

\section{Bibliography}

1. Ackermann, Barbara. Das Analogieverbot im geltenden und zukuenftigen Strafrecht (Breslau-Neukirch, 1934).

2. Anosov, Iosif. "Zametki k voprosu o primenenii analogii v ugolovnom prave" ["Remarks on the Application of Analogy in Criminal Law"], Biulleten Sredne-aziatskogo gosudarstvennogo universiteta 5 (1926): c. 1-18 [in Russian].

3. Bar, Ludwig. Handbuch des Deutschen Strafrechts. B. 1 (Berlin, 1882).

4. Dagel, Plekhan. "Ob analogii v sovetskom ugolovnom prave" ["On the Analogy in Soviet Criminal Law"], Rossiiskii kriminologicheskii vzgliad 4 (2009): c. 82-86 [in Russian].

5. Danckert, Peter. Die Grenze zwischen der extensiven Auslegung und der Analogie im Strafrecht: Inaugural-Dissertation zur Erlangung der Doktorwuerde (Koeln, 1967).

6. Drobyshevsky, Sergei, Tikhonravov, Evgeny. Sposoby vospolneniia probelov v prave [Methods of Filling Gaps in the Law] (Moscow: Norma, 2014) [in Russian].

7. Dubrovin, Fedor. "O razmerakh dopustimosti analogii pri primenenii ugolovnogo zakona" ["On the Scope of Admissibility of Analogy in Criminal Law Application"], Zhurnal ministerstva iustitcii 5 (1899): c. 107-138 [in Russian].

8. Dubrovin, Fedor. "O razmerakh dopustimosti analogii pri primenenii ugolovnogo zakona (okonchanie)" ["On the Scope of Admissibility of Analogy in Criminal Law Application (ending)"], Zhurnal ministerstva iustitcii 6 (1899): c. 1-35 [in Russian].

9. Ehrlich, Eugen. Die juristische Logik (Tuebingen, 1925).

10. Feuerbach, Anselm. Lehrbuch des gemeinen in Deutschland gueltigen peinlichen Rechts (Giessen: Georg Friedrich Heyer's Verlag, 1847).

11. Gessen, Iosif. "Tvorcheskaia rol suda (primery iz praktiki)" ["Creative Function of the Court: Examples from Practice"], Zhurnal ministerstva iustitcii 6 (1897): c. 204-225 [in Russian].

12. Glaser, Stefan. "Nullum Crimen Sine Lege", Journal of Comparative Legislation and International Law 24(1) (1942): 29-37.

13. Hall, Jerome. "Nulla Poena Sine Lege", The Yale Law Journal 47(2) (1937): 165-193.

14. Hippel, Robert. Deutsches Strafrecht. B. 1 (Berlin, 1925).Google Scholar

15. Jhering, Rudolf. Law as a Means to an End (Boston: The Boston Book Company, 1913).

16. "K razrabotke proekta obshchei chasti Ugolovnogo kodeksa SSSR" ["On the Draft of the General Part of the Criminal Code of the USSR"], Sovetskaia iustitciia 20-21 (1938): c. 18-19 [in Russian].

17. Kaufman, Mikhail. Probely v ugolovnom prave i sposoby ikh preodoleniia: avtoreferat dissertacii doktora iuridicheskikh nauk [Gaps in Criminal Law and Methods of their Filling: A Summary of a PhD Thesis in Law] (Moscow, 2009) [in Russian].

18. Krey, Volker. Studien zum Gesetzesvorbehalt im Strafrecht: Eine Einfuehrung in die Problematik des Analogieverbots (Berlin: Duncker \& Humblot, 1977).

\footnotetext{
${ }^{57}$ Maris, supra note 22, at 71

58 Ibid.
} 
19. Lapenna, Ivo. "The New Russian Criminal Code and Code of Criminal Procedure, I", The International and Comparative Law Quarterly 10(3) (1961): 421-453.

20. Liublinsky, Pavel. Tehnika, tolkovanie i kazuistika Ugolovnogo kodeksa [Technique, Interpretation and Casuistry of the Criminal Code] (Petrograd, 1917) [in Russian].

21. Locke, John. Two Treatises of Government (London, 1821).

22. Maris, Cornelis Willem. "Milking the Meter-On Analogy, Universalizability and World Views", in Patrick Nerhot (ed.), Legal Knowledge and Analogy: Fragments of Legal Epistemology, Hermeneutics, and Linguistics (Kluwer Academic Publishers, Dordrecht, 1991), 71-106.

23. Mokhtar, Aly. "Nullum Crimen, Nulla Poena Sine Lege: Aspects and Prospects", Statute Law Review 26(1) (2005): 41-55.

24. "Poniatie analogii v sovetskom ugolovnom prave i praktika ee primeneniia" ["The Notion of Analogy in Soviet Criminal Law and Practice of its Application"], Sovetskaia iustitciia 3 (1939): c. 8-13 [in Russian].

25. Pound, Roscoe. An Introduction to the Philosophy of Law (Clark, New Jersey, 2003).

26. Preuss, Lawrence. "Punishment by Analogy in National Socialist Penal Law", Journal of Criminal Law and Criminology 26(6) (1936): 847-856.

27. Pustoroslev, Petr. Programma lekcii po obshhei chasti russkogo ugolovnogo prava s kratkim izlozheniem nekotoryh poniatii i obiasnenii [Lectures on the General Part of the Russian Criminal Law with Brief Explanation of Some Concepts] (Yuryev, 1904) [in Russian].

28. Rejewski, Erwin. Die Stellung des Strafrichters zur 'Schuldfrage' unter dem Gesichtswinkel der Abgrenzung der ausdehnenden Auslegung zur Analogie: Inaugural-Dissertation zur Erlangung der Doktorwuerde (Breslau-Neukirch, 1937).

29. Schreiber, Hans-Ludwig. Gesetz und Richter. Zur geschichtlichen Entwicklung des Satzes nullum crimen, nulla poena sine lege (Alfred Metzner Verlag GmbH, Frankfurt am Main, 1976).

30. Shargorodsky, Mikhail. "Analogiia $\mathrm{v}$ istorii ugolovnogo prava i v sovetskom ugolovnom prave" ["Analogy in the History of Criminal Law and in Soviet Criminal Law"], Sotcialisticheskaia zakonnost 7 (1938): c. 50-60 [in Russian].

31. Spasovich, Vladimir. Uchebnik ugolovnogo prava. T. 1 [A Textbook on Criminal Law, vol. 1] (St. Petersburg, 1863) [in Russian].

32. "The Use of Analogy in Criminal Law", Columbia Law Review 47(4) (1947): 613-629.

33. Vogenauer, Stefan. Die Auslegung von Gesetzen in England und auf dem Kontinent. B. 1 (Mohr Siebeck, Tuebingen, 2001). 